CASE REPORT

\title{
The Skin and the Eye - Herpes Zoster Ophthalmicus in a Healthy 18-month-old Toddler
}

\author{
Radka T. Komitova ${ }^{1}$, Oliana B. Boykinova ${ }^{1}$, Nina S. Stoyanova ${ }^{2}$ \\ ${ }^{1}$ Department of Infectious Disease, Parasitology and Tropical Medicine, Faculty of Medicine, Medical University of Plovdiv, \\ Plovdiv, Bulgaria \\ 2 Department of Ophthalmology, Faculty of Medicine, Medical University of Plovdiv, Plovdiv, Bulgaria
}

\section{Correspondence:}

Radka T. Komitova, Department of Infectious Disease, Parasitology and Tropical Medicine, Faculty of Medicine, Medical University of Plovdiv, 15A Vassil Aprilov Blvd., 4002 Plovdiv, Bulgaria

E mail: radkakomitova@yahoo.com Tel: +35932123456

Received: 23 May 2017

Accepted: 24 June 2017

Published Online: 12 July 2017

Published: 30 March 2018

Key words: varicella-zoster virus, herpes zoster ophthalmicus, infancy

Citation: Komitova RT, Boykinova OB, Stoyanova NS. The skin and the eye - herpes zoster ophthalmicus in a healthy 18-monthold toddler. Folia Med (Plovdiv) 2018;60(1):170-4.

doi: 10.1515/folmed-2017-0064
Herpes zoster, caused by reactivation of varicella-zoster virus, is uncommon in infancy. Even more uncommon is herpes zoster ophthalmicus, defined as herpes zoster of the ophthalmic branch of the fifth cranial nerve. Among healthy children, primary varicella-zoster virus infection during gestation as a result of maternal varicella or the first year of life is the major risk factor for development of herpes zoster in a relatively young age. Here we present an unusual case of herpes zoster ophthalmicus with dissemination in an immunocompetent toddler with favorable outcome. The child's mother contracted chickenpox in late pregnancy and her son was very likely infected with varicella-zoster virus in utero. During a two-year follow-up the child vision was normal and there was no evidence of post herpetic neuralgia.

\section{INTRODUCTION}

Herpes zoster (HZ), also known as shingles, is caused by reactivation of latent varicella-zoster virus (VZV) infection within the sensory ganglia. Herpes zoster demonstrates the characteristic skin rash with dermatomal distribution, typically without crossing the midline. The development of HZ is associated with a decline in cell-mediated immunity due to aging, immunosuppressive illness and treatment or with immature cell-mediated immune system. ${ }^{1,2}$ Herpes zoster ophthalmicus (HZO) is a relatively common presentation of shingles. ${ }^{3}$ However, HZ is infrequent in childhood and $\mathrm{HZO}$ is even less common. There are a few studies on HZ in infancy in Bulgaria. ${ }^{4}$ Herein we report an unusual case of disseminated $\mathrm{HZO}$ in an immunocompetent toddler.

\section{CASE REPORT}

A previously healthy 18-month-old boy was admitted to infectious disease department, St. George University Hospital, Plovdiv in January 2015 because of a 3-day history of rash on his face and drowsiness, but without temperature. The child had been a full-term normal delivery with a birth weight of $3.6 \mathrm{~kg}$, was breast-fed for the first 6 months of life, and had been fully immunized to date.

On presentation the child was afebrile but restless. There were grouped vesicles on the right side of the forehead, spreading to the nasal bridge but sparing the tip of the nose. The right upper eyelid was swollen and erythematous. The right bulbar conjunctiva was injected with clear discharge (Fig. 1). The remainder of examination was without abnormalities, including lack of meningeal irritation. Diagnosis of HZO was established. The consultant ophthalmologist revealed subconjunctival hemorrhages without corneal scarring. The child was commenced on intravenous fluids, intravenous 
acyclovir $10 \mathrm{mg} / \mathrm{kg}$ three times daily for 7 days, topical acyclovir 3\% eye ointment and ceftriaxone $50 / \mathrm{mg} / \mathrm{kg}$ on suspicion of bacterial superinfection. Routine blood tests were without abnormalities as was cerebrospinal fluid. Three days later a few scattered vesicles appeared on the trunk and limbs, accompanied by low-grade fever (Fig. 2). In a week the rash crusted over and five days later resolved leaving a residual purplish skin discoloration. The child was discharged markedly improved. A serologic test done on day 6 of illness revealed anti-VZV IgG positive and anti-VZV IgM negative antibodies results. The child's mother had contracted chickenpox in late pregnancy and her son was very likely infected with VZV in utero. During a two-year follow-up the child vision was

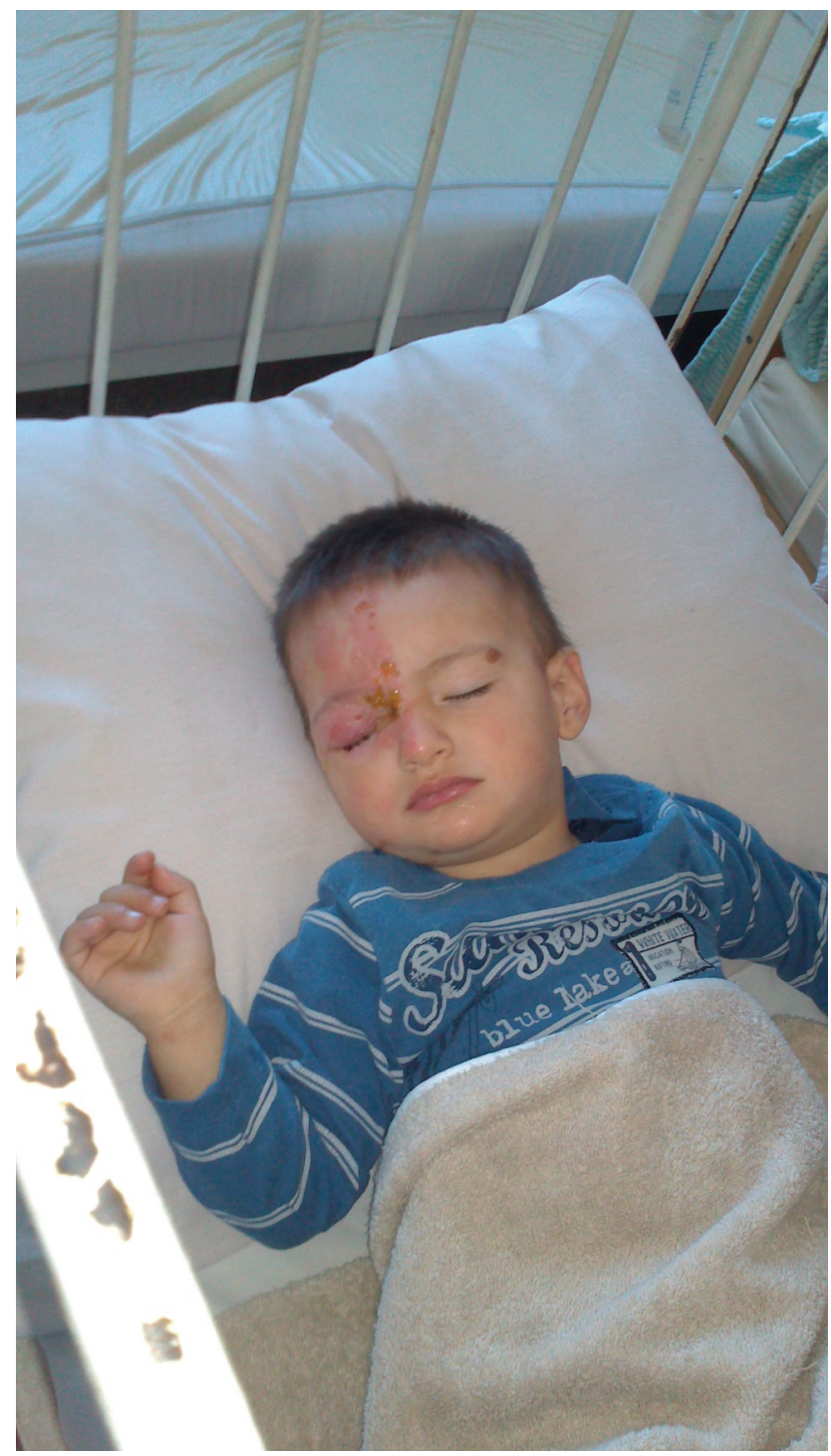

Figure 1. A 18-month-old boy with herpes zoster opthalmicus. normal and there was no evidence of post herpetic neuralgia.

Parental consent to publish personal health information was obtained.

\section{DISCUSSION}

$\mathrm{HZ}$ is rare in the paediatric age group and its incidence ranges from 0.2 to 0.75 cases per 1000 person-years. A higher incidence rate, up to 1.6 cases per 1000 person-years was reported from Iceland. ${ }^{5,6}$ It is possible that the disease occurs more frequently in children that it is thought, but remains undiagnosed and underreported because of its benign course, as many parents would not seek medical care. ${ }^{4}$

Historically, childhood HZ was thought to be

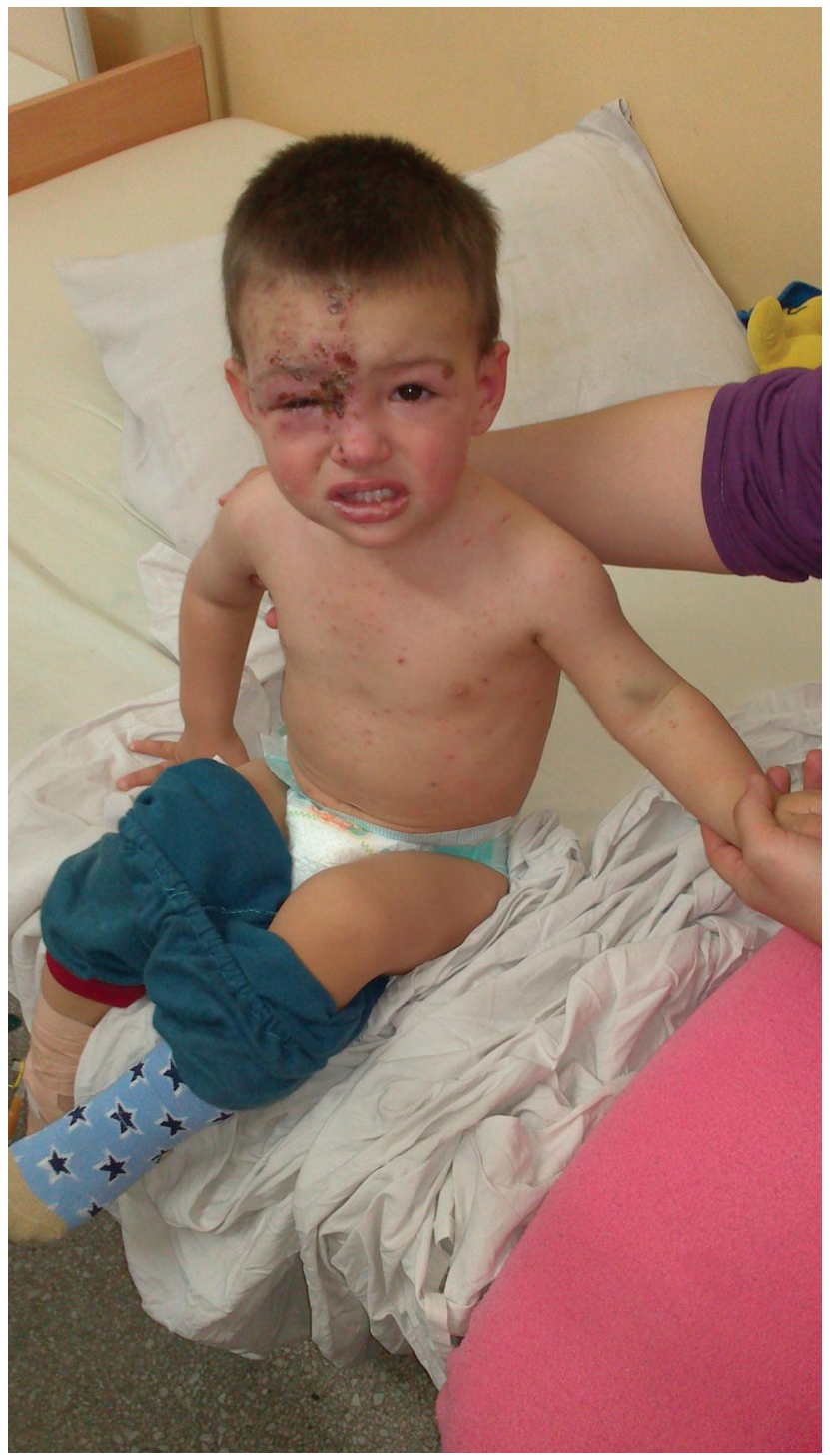

Figure 2. A 18-month -old boy with herpes zoster opthalmicus and dissemination. 
an indicator of underlying malignancy or immunosuppression. However, most cases of childhood $\mathrm{HZ}$ occur in otherwise healthy children and only $3 \%$ of pediatric $\mathrm{HZ}$ cases are associated with malignancies. ${ }^{7}$ Among healthy children, primary VZV infection during gestation as a result of maternal varicella or in the first year of life is the major risk factor for development of $\mathrm{HZ}$ in a relatively young age. Baba et al. ${ }^{5}$ calculated an even higher incidence rate of 4.1 per 1000 person-years in children, acquiring varicella when younger than one year of age. Approximately $2 \%$ of children who were exposed to VZV in utero can develop inapparent chickenpox and therefore they are at risk for zoster after birth. ${ }^{8}$ Vaccine with live attenuated VZV may also contribute. However, vaccinated children appear to have a much lower risk of HZ. ${ }^{9}$

HZ in healthy children usually runs a mild symptomatic and self-limited course. Post-zoster neuralgia occurs rarely. ${ }^{10}$ Zoster affects the cranial nerves in $5 \%$ of children vs. $13 \%$ of adults. ${ }^{11,12}$ Dissemination (more than 20 lesions outside the primary and adjacent affected dermatomes) is rare in adults and less common in children. In immunocompromised patients cutaneous dissemination is often accompanied by visceral involvement. There were few reports for disseminated $\mathrm{HZ}$ in healthy infants after uterine exposure. ${ }^{13}$

$\mathrm{HZO}$, which refers to the involvement of the ophthalmic branch of the trigeminal nerve (V1), accounts for $10-25 \%$ of all $\mathrm{HZ}$ cases. ${ }^{11}$ The typical unilateral painful dermatomal rash appears in the distribution of one or more branches of V1: supraorbital, lacrimal and nasocilliary. Erythematous papules around the eyelid, forehead and scalp, quickly evolve into grouped vesicles or bullae and within three or four days can become more pustular. The lesions crust by 7 to 10 days. HZO may lead to severe pain and a wide spectrum of complications affecting all ocular and orbital tissues. Nevertheless, ocular manifestations are not invariable for HZO as was in the case described. They affect about $50 \%$ of patients with typical $\mathrm{HZ}$ rash. Common ocular involvements include keratitis, iritis and optic neuritis but any structure in the eye may be affected. Nasocilliary branch involvement known as Hitchinson's sign is believed to herald ocular involvement. It is clinically manifested by the skin involvement of the tip of the nose. ${ }^{14}$

Being very frequent in adults, this condition is rare in childhood. HZO in children has sudden onset with severe constitutional symptoms, but follows a mild course and healing occurs within weeks. Although sometimes HZO results in scarring, visual loss is rare. ${ }^{20}$

Diagnosis is made usually on clinical grounds. Additional diagnostic testing may be useful when considering $\mathrm{HZ}$ in immunocompromised host or evaluation of atypical lesions. Diagnostic methods performed on blister fluid/corneal lesions include Tzanck smear (demonstrating giant cells), viral culture and direct immunofluoresent assay. These tests have largely been replaced by polymerase chain reaction (PCR) - the most sensitive test developed yet. PCR technique is valuable in rapidly confirming the diagnosis of $\mathrm{HZ}$, especially in immunocompromised subjects. Detection of the presence of high or rising titers of antibodies to VZV, although rarely used today, can also be helpful. ${ }^{16-18}$ Due to unavailability of PCR we use serology for confirmation, indicating past exposure. Acyclovir is the first choice treatment for children and the suggested dose is $10 \mathrm{mg} / \mathrm{kg}$ every 8 hours for 7 days. Starting within 72 hours of initial symptoms significantly reduces adverse outcome. Topical steroids are recommended for treatment of conjunctival, corneal and uveal inflammation. Post herpetic neuralgia can be reduced by treating the patient with antiviral within the first 24 hours of symptom onset. ${ }^{19}$

As HZ in children does not always imply an underlying immunodeficiency or malignancy, immunologic follow-up should not be routinely performed in previously healthy children. It would be justified when a recurrence occurs. ${ }^{20}$

\section{CONCLUSION}

In conclusion, this case report presents a rare and an unusual form of $\mathrm{HZ}$ in children - HZO with dissemination but without ocular involvement. It has emphasized the importance of early clinical suspicion of HZO in immunocompetent toddler. Prompt clinical diagnosis enables timely commencement of acyclovir to prevent any sight-threatening sequelae. This rare potentially serious complication might develop without history of varicella as primary infection had occurred in utero.

\section{REFERENCES}

1. Gershon A, Gershon M, Breuer J, et al. Advances in the understanding of the pathogenesis and epidemiology of herpes zoster. J Clin Virol 2010;48:52-7.

2. Cotton D, Taichman D, Williams S. In the clinic: herpes zoster. Ann Intern Med 2011;154:ITC1-14. 
3. Rousseau A, Bourcier T, Colin J, et al. Herpes zoster ophthalmicus - diagnosis and management. US Ophth Review 2013;6(2):119-24.

4. Dobrev Ch. Herpes zoster in infants. Folia Med (Plovdiv). 1994;36(4):45-9.

5. Baba K, Yabuuchi H, Takahashi M, et al. Increased incidence of herpes zoster in normal children infected with varicella zoster virus during infancy: community-based follow-up study. J Pediatr 1986;108(3):372-7.

6. Petursson G, Helgason S, Gudmundsson S, et al. Herpes zoster in children and adolescents. Pediatr Infect Dis J 1998;17(10):905-8.

7. Takayama N, Yamada H, Kaku H, et al. Herpes zoster in immunocompetent and immunocompromised Japanese children. Pediatr Int 2000;42:275-9.

8. Leung AK. Herpes Zoster. In: Leung AK, editor. Common problems in ambulatory pediatrics: specific clinical problems. vol. 1, New York: Nova Science Publishers, Inc.; 2011. p. 285-9.

9. Weinmann S, Chun C, Schmid D, et al. Incidence and clinical characteristics of herpes zoster among children in the varicella vaccine era, 2005-2009. J Infect Dis 2013;208(11):1859-68.

10.Leung A, Rafaat M. Herpes Zoster. Am Family Phys 2003;67:1045-6.

11. Brodell R, Zurakowski J. Childhood shingles. Herpes zoster can occur in healthy children too. Postgrad Med 2004;115:63-5.
12. Ragozzino M, Melton L 3rd, Kurland L, et al. Population-based study of herpes zoster and its sequelae. Medicine (Balt) 1982;61:310-6.

13. Chiang C, Chiu C, Huang Y, et al. Two cases of disseminated cutaneous herpes zoster in infants after intrauterine exposure to varicella-zoster virus. Pediatr Infect Dis J 1995;14(5):395-7.

14.Zaal M, Wolker-Dieben HJ, D'Amaro J. Prognostic value of Hutchinson's sing in acute herpes zoster ophthalmicus. Graefe's Arch Clin Exp Ophthalmol 2003;241:187-91.

15. De Freitas D, Martins E, Adan C, et al. Herpes zoster ophthalmicus in otherwise healthy children. Am J Ophthalmol. 2006;142(3):393-9.

16. Uebe B, Sauerbrei A, Burdach S, et al. Herpes Zoster by reactivated vaccine varicella zoster virus in a healthy child. Eur J Pediatrics 2002;161:442-4.

17. Chun C, Weinman S, Riedlinger K, et al. Laboratory characteristics of suspected herpes zoster in vaccinated children. Ped Infect Dis J 2011;30:719-21.

18. Williams V, Gershon A, Brunell P. Serologic response to varicella-zoster membrane antigens measured by direct immunofluorescence. J Infect Dis 1974; 130:669-72.

19. Opstelten W, Eekhof J, Neven A, et al. Treatment of herpes zoster.Can Fam Physician 2008;54:373-7.

20. Donahue J, Choo O, Manson J, et al. The incidence of herpes zoster. Arch Inter Med 1995;155:1605-9. 


\title{
Кожа и глаза - Herpes Zoster Ophthalmicus у здорового восемнад- цатимесячного ребёнка
}

\author{
Радка Т. Комитова ${ }^{1}$, Олиана Б. Бойкинова ${ }^{1}$, Нина С. Стоянова ${ }^{2}$ \\ ${ }^{1}$ Кафедра инфекционных заболеваний, паразитологии и тропической медицины, Факультет медицины, Медицинский \\ университет - Пловдив, Пловдив, Болгария \\ 2 Кафедра офтальмологии, Факультет медицины, Медицинский университет - Пловдив, Пловдив, Болгария
}

\begin{abstract}
Адрес для корреспонденции: Радка Т. Комитова, Кафедра инфекционных заболеваний, паразитологии и тропической медицины, Факультет медицины, Медицинский университет - Пловдив, бул. „Васил Априлов“ № 15A, 4002, Пловдив, Болгария E mail: radkakomitova@yahoo. com

Tel: +35932123456
\end{abstract}

Дата получения: 23 мая 2017 Дата приемки: 24 июня 2017 Дата онлайн публикации: 12 июля 2017

Дата публикации: 30 марта 2018

Ключевые слова: VaricellaZoster вирус, herpes zoster ophthalmicus, раннее детство

\section{Образец цитирования:}

Komitova RT, Boykinova OB, Stoyanova NS. The skin and the eye - herpes zoster ophthalmicus in a healthy 18-month-old toddler. Folia Med (Plovdiv) 2018;60(1):170-4. doi: 10.1515/folmed-2017-0064
Herpes zoster, вызванный реактивацией varicella-zoster вируса, является редким случаем в раннем детстве. Herpes zoster ophthalmicus, известный ещё как herpes zoster оптической ветви пятого черепного нерва, считается исключительно редким. Среди здоровых младенцев, первичная инфекция вирусом varicella-zoster во время беременности, вызванная ветряной оспой матери или во время первого года жизни является главным фактором риска развития опоясывающего лишая в сравнительно раннем возрасте. Здесь нами представлен редкий случай herpes zoster ophthalmicus c paспространением у иммунокомпетентного маленького ребёнка с благоприятным исходом. Заражение матери ветряной оспой произошло на поздней стадии беременности и вероятнее всего заражение плода вирусом varicella-zoster является внутриутробным. В течение двухлетнего наблюдения зрение ребёнка оставалось нормальным и не установлены признаки постгерпетической невралгии. 